\title{
DEVELOPMENT OF TREATMENT TECHNOLOGY FOR PATIENTS WITH ANEMIA IN NEOPLASTIC DISEASE IN COLORECTAL CANCER WITH DRUG-CONTAINING ARGININE GLUTAMATE
}

\author{
Andriiaka A. O., Vydyborets S. V. \\ Shupyk National Healthcare University of Ukraine, Kyiv, Ukraine
}

\begin{abstract}
Introduction. Colorectal cancer is one of the most common oncological diseases. This problem becomes especially urgent in the case of the formation of an anemic syndrome in patients, which causes the emergence of a mutual burden syndrome and increases the risks for a patient. The progressive nature of anemia in colorectal cancer (CRC) is accompanied by secondary metabolic disorders.

Aim. Optimize treatment tactics in patients with anemia of malignant neoplasms in CRC, taking into account secondary metabolic disorders.

Materials and methods. The material for the study was the blood plasma of 445 patients (228 men and 217 women). Among them, 53 patients (31 women and 22 men) with iron deficiency anemia (IDA) were examined and included in the first observation group (I) and 392 patients (206 men (52.55\%) and 186 women $(47,45 \%)$ ) with CRC whose course of the underlying disease was burdened with anemia in neoplastic disease (AND, ICD-10 code: D63.0) were included in the second observation group (II). Among the patients in the second (II) observation group, there were 222 individuals (119 men and 103 women) with malignant neoplasms of the colon (ICD-10 code: C.18), 29 individuals (16 men and 13 women) with malignant neoplasms of the rectosigmoid junction (ICD-10 code: C.19), 138 individuals (82 men and 56 women) with malignant neoplasms of the rectum (code ICD-10 C.20) and 3 patients ( 2 men and 1 woman) with malignant neoplasms of the anus (ICD-10 code: C.21). The age of the examined patients was from 22 to 79 years. The mean age of the patients was $(63.3 \pm 1.2)$ years. The plasma level of the free fraction of heparin (FHN) of the examined patients was determined using the photocolorimetric method on photoelectric colorimeter FEC 56-M after its preliminary isolation by the electrophoretic method. The plasma level of free fractions of histamine (FH) and serotonin (FS) of the examined patients were studied using the method of fluorometric analysis on the analyzer «BIAN-130»-«BIAN-100».
\end{abstract}

Results. It was found that prior to the initiation of treatment in patients with AND, regardless of the course of $C R C$, there was a significant increase in the plasma level of $F H N, F H, F S(p<0,001)$; the ratio of FH:FS was also changed in comparison with the values in the control group $(p<0,05)$, which indicated both an increased release of 
heparin, histamine, and serotonin from the depot, and impaired inactivation processes of these biologically active substances.

Considering all of the above and the quite obvious reasons, namely, the secondary metabolic disorders of serotonin, histamine, heparin which manifested by a significant increase in their plasma level of patients with $A N D$ in $C R C$, we suggested the need to use a medicinal product in a complex of therapeutic measures which can cause antihypoxic, membrane stabilizing and anti-edema action.

Conclusions. Anemia in neoplastic disease in CRC is accompanied by significant changes in the metabolism of biologically active substances - free fractions of heparin, histamine, serotonin, and the ratio of free histamine to serotonin. It was correctly concluded that in addition to the baseline therapy the administration of arginine glutamate which causes both antihypoxic and membrane-stabilizing action, reliably contributes to the normalization of secondary metabolic disorders of histamine, serotonin and heparin metabolism in anemia in neoplastic disease in patients with CRC. Keywords: colorectal cancer, anemia in neoplastic disease, free histamine, free serotonin, free heparin, blood plasma.

Competing interests: the authors declare no conflict of interests in relation to this article.

Financing resources: research had no industry funding.

\title{
РОЗРОБКА ТЕХНОЛОГІЇ ЛІКУВАННЯ ПАЦІЕНТІВ ІЗ АНЕМІЕЮ ЗЛОЯКІСНОГО НОВОУТВОРЕННЯ ПРИ КОЛОРЕКТАЛЬНОМУ РАКУ ЛІКАРСЬКИМ ПРЕПАРАТОМ, ЩО МІСТИТЬ АРГІНІНУ ГЛУТАМАТ
}

\author{
Андріяка А. О., Видиборець С. В. \\ Національний університет охорони здоров'я Украӥни імені П. Л. Шупика, \\ Київ, Україна
}

\begin{abstract}
Резюме
Вступ. Колоректальний рак (КРР) $є$ одним із найпоширеніших онкологічних захворювань кишківника. Особливої актуальності дана проблема набуває у разі формування у пацієнтів анемії, щзо обумовлює виникнення взаємного обтяження захворювань $і$ збільшує ризики для пацієнта. Прогресуючий характер анемї при КРР супроводжується вторинними метаболічними порушеннями.
\end{abstract}

Мета. Оптимізувати лікувальну тактику у пацієнтів із анемією злоякісного новоутворення при КРР із урахуванням вторинних метаболічних порушень.

Матеріали $\boldsymbol{i}$ методи. Матеріалом для дослідження була плазма крові 445 пацієнтів (228 чоловіків і 217 жінок), серед яких обстежено 53 паціснти (31 жінка і 22 чоловіки) із ЗДА, вони склали першу (I) групу спостереження та 392 пацієнти (206 чоловіків (52,55\%) та 186 жінок (47,45\%)) із КРР, перебіг основного захворювання у яких обтяжувався анемією злоякісного новоутворення 
(АЗН - друга (II) група спостереження. Серед пацієнтів другої (II) групи спостереження було 222 осіб (119 чоловіків та 103 жінки) із злоякісними новоутвореннями ободової кишки (иифр МКХ-10 С.18), 29 осіб (16 чоловіків та 13 жінок) із злоякісними новоутвореннями ректосигмоїдального відділу (иифр МКХ-10 С.19), 138 осіб (82 чоловіки та 56 жінок) із злоякісними новоутвореннями прямої кишки (шифр МКХ-10 С.20) та 3 пацієнти (2 чоловіки та 1 жінка) із злоякісними новоутвореннями анального каналу (шифр МКХ-10 С.21). Вік обстежених від 22 до 79 років. Середній вік пацієнтів становив (63,3 1,2) років. Визначення вмісту вільної фракиії гепарину (ВФГ) у плазмі крові обстежених здійснювали фотоколориметричним методом на ФЕК 56-М після попереднього його виділення електрофоретичним шляхом. Дослідження вмісту вільних фракцій гістаміну (BГ) і серотоніну (BC) у плазмі крові обстежених здійснювали методом флуориметричного аналізу на аналізаторі «БИАН-130»-«БИАН-100».

Результати. Встановлено, що до початку призначення лікування у пацієнтів із АЗН незалежно від перебігу КРР мало місце достовірне збільшення показників вмісту ВФГ, ВГ, ВС у плазмі крові $(p<0,001)$, також порушувалося спів відночення ВГ:ВС порівняно із значеннями у групі контролю $(p<0,05)$, щуо свідчило як про посилене вивільнення гепарину, гістаміну $і$ серотоніну із депо, так $i$ про порушення прочесів інактивації означених біологічно активних речовин.

Враховуючи виявлені вторинні порушення обміну серотоніну, гістаміну, гепарину, щзо проявлялись достовірним підвищенням їх вмісту у плазмі крові пацієнтів із АЗН при КРР, ми припустили можливість застосування у комплексі лікувальних заходів препарату, що здатен викликати антигіпоксичну, мембраностабілізуючу, протинабрякову дію.

Висновки. Призначення до базисної терапї додатково аргініну глутамату, який викликає як антигіпоксичну, так і мембраностабілізуючу дію, достовірно сприяє нормалізації вторинних метаболічних порушень обміну гістаміну, серотоніну $i$ гепарину при АЗН у пацієнтів із КРP.

Ключові слова: колоректальний рак, анемія злоякісного новоутворення, вільний серотонін, вільний гепарин, вільний гістамін, плазма крові.

\section{Introduction}

Anemia is one of the most frequent complications of cancer [1, 2]. It occurs both as a result of the onset, development, and progression of the tumour process, and cytostatic and/or radiation therapy, which is used to treat cancer, the presence of hemolysis, splenomegaly, hemorrhagic syndrome, hemodilution, ineffective erythropoiesis, impaired regulation of iron metabolism in the patient's body, the key link of which is now considered to be changes in the hepcidin synthesis [3]. This type of anemia is called anemia in neoplastic disease (AND), and the nosological form of this anemia is included in the headings of the International Classification of Diseases (ICD) under the code D63.0. It is believed that an essential link in the AND pathogenesis is the 
absence of a compensatory increase in the rate of erythrocyte production, as well as a negative effect on the bone marrow (BM) of cytostatic drugs [4-6].

Long-term studies of the causes of tumours have led to the conclusion that tumour progression is the result of loss of control over cell replication due to mutation, after which the cell has an inherent potential for uncontrolled proliferation $[1,2]$.

Until now, there is a debate about whether metabolic changes are the primary factor triggering carcinogenesis or the tumour transformation of cells initiated due to other reasons that trigger pathological variants of cell metabolism. But the fact of the strict dependence of tumour cells on the supply of ATP as a result of intense glycolysis remains such that there is no doubt. Tumour cells are metabolically heterogeneous, that is, they are able to change metabolism to adapt to existence in conditions of competition for energy substances with cells of the normal microenvironment. It is known that different types of tumour cells can function by different bioenergetic mechanisms, for example, glycolysis and phosphorylation [7, 8]. In addition to glucose, tumour cells are able to metabolize alternative energy sources - fatty acids and amino acids. The mechanisms of regulation of these processes have not yet been sufficiently studied.

Anemia is accompanied by the development of hemic hypoxia, which in turn causes a wide range of metabolic disorders characteristic of the common pathophysiological process - hypoxia, in particular, excessive release of histamine, serotonin, heparin (the metabolism of which is closely related) [9-12].

Glutathione system in managing cancer patients is has been actively studied for over three decades [13].

Theoretically, the justification of the strategy for the prevention of malignancies is the use of antioxidants or stimulation of cellular antioxidant activity. However, the findings of the experimental studies in this matter are questionable. Increased glutathione levels were found to be associated with proliferation of both normal and malignant cells.

Aim. Optimize treatment tactics in patients with anemia of malignant neoplasms in CRC, taking into account secondary metabolic disorders.

\section{Materials and methods}

This clinical study was conducted based on the Kyiv Regional Oncological Dispensary. The material for the study was the blood plasma of 445 patients (228 men and 217 women). Among them, 53 patients ( 31 women and 22 men) with iron deficiency anemia (IDA) were examined and included in the first observation group (I) and 392 patients (206 men (52.55\%) and 186 women 
$(47.45 \%)$ ) with colorectal cancer (CRC) whose course of the underlying disease was burdened with anemia in neoplastic disease (AND) were included in the second observation group (II). Among the patients in the second (II) observation group, there were 222 individuals (119 men and 103 women) with malignant neoplasms of the colon (ICD-10 code: C.18), 29 individuals (16 men and 13 women) with malignant neoplasms of the rectosigmoid junction (ICD10 code: C.19), 138 individuals (82 men and 56 women) with malignant neoplasms of the rectum (code ICD-10 C.20) and 3 patients ( 2 men and 1 woman) with malignant neoplasms of the anus (ICD-10 code: C.21). The age of the examined patients was from 22 to 79 years. The mean age of the patients was $(63.3 \pm 1.2)$ years. The anemic syndrome was present in the examined patients upon admission to the hospital. The presence of colorectal cancer of Stage IIIIV according to S. E. Dukes (1956) was determined histochemically. All patients were examined prior to the initiation of any treatment.

The severity of anemia was determined according to the criteria proposed by the National Cancer Institute (USA) and was allocated as: mild anemia hemoglobin 10-12 g/dL; moderate anemia - 8-10 g/dL; severe anemia - 6.5$8 \mathrm{~g} / \mathrm{dL}$; life-threatening anemia - below $6.5 \mathrm{~g} / \mathrm{dL}$. Among patients with IDA, 19 people were diagnosed with mild IDA, 15 people - with moderate IDA, 11 people - with severe IDA, and 8 people - with life-threatening IDA. Mild AND in CRC was diagnosed in 172 patients (92 men and 80 women), moderate - in 114 patients ( 66 men and 48 women), severe - in 78 people ( 32 men and 48 women), and life-threatening - in 28 patients (16 men and 12 women). The control group consisted of 50 primary blood donors who had no history of oncological or chronic inflammatory diseases.

The plasma level of the free fraction of heparin (FHN) of the examined patients was determined using the photocolorimetric method on photoelectric colorimeter FEC 56-M after its preliminary isolation by the electrophoretic method according to the appropriate procedure [14]. The plasma level of free fractions of histamine (FH) and serotonin (FS) of the examined patients were studied using the method of fluorometric analysis on the analyzer «BIAN$130 »-\langle$ BIAN-100» according to the procedure of B. V. Mykhailychenko, S. V. Vydyborets (1999) [15].

Patients with mild and moderate anemia $(n=286)$ received basic therapy with iron preparations intravenously under the control of peripheral blood parameters; in addition to the administration of iron preparations patients with severe AND $(\mathrm{n}=78)$ received erythropoietin preparation; and in addition to iron and erythropoietin preparations patients with life-threatening anemia $(\mathrm{n}=28)$ received transfusions of erythrocytes. Depending on the therapy, some 
patients (observation group IIA) with AND in CRC, in addition to the basic therapy, received arginine glutamate, which is well-known and has proven itself as a hepatoprotector, which is positive in this clinical situation and due to its composition causes both antihypoxic and membrane stabilizing action. The study results were processed using the methods of variation statistics by calculating the Student's t-test $(\mathrm{p}<0,05)$.

\section{Results and discussion}

Data on the parameters of the plasma level of FHN, FH, FS of control group are given in Table 1.

\section{Table 1. Plasma level of FHN, FH, FS of healthy subjects $(\mathbf{M} \pm \mathbf{m})$}

\begin{tabular}{|l|c|c|c|c|}
\hline $\begin{array}{c}\text { Studied } \\
\text { parameter, unit } \\
\text { of measurement }\end{array}$ & $\begin{array}{c}\text { Total } \\
(\mathbf{n}=\mathbf{5 0})\end{array}$ & $\begin{array}{c}\text { Men } \\
(\mathbf{n}=\mathbf{2 9})\end{array}$ & $\begin{array}{c}\text { Women } \\
(\mathbf{n}=\mathbf{2 1})\end{array}$ & $\begin{array}{c}\text { Significance } \\
\text { of differences } \\
(\mathbf{p})\end{array}$ \\
\hline Level of $\mathrm{FHN},(\mu \mathrm{g} / \mathrm{g})$ & $21.28 \pm 0.51$ & $21.41 \pm 0.75$ & $20.96 \pm 1.15$ & $\mathrm{p}>0.1$ \\
\hline Level of $\mathrm{FH},(\mathrm{nmol} / \mathrm{g})$ & $1.45 \pm 0.14$ & $1.45 \pm 0.16$ & $1.46 \pm 0.30$ & $\mathrm{p}>0.1$ \\
\hline Level of $\mathrm{FS},(\mathrm{nmol} / \mathrm{g})$ & $0.59 \pm 0.05$ & $0.59 \pm 0.09$ & $0.57 \pm 0.07$ & $\mathrm{p}>0.1$ \\
\hline Ratio FH: FS & $2.78 \pm 0.25$ & $2.79 \pm 0.30$ & $2.76 \pm 0.49$ & $\mathrm{p}>0.1$ \\
\hline
\end{tabular}

Note: $\mathrm{p}$ - the significance of differences between values depending on gender

The obtained data of biochemical parameters of blood on the plasma level of FHN, FH, FS of primary donors can be used as controls when conducting a comparative analysis.

Hypoxia is a typical pathological condition that always accompanies anemic syndrome. Of course, the assumption about the importance of pathophysiological changes in the plasma level of histamine, serotonin, and heparin in patients with CRC accompanied by the development of anemia of neoplasm disease will be reasonable. In our opinion, special attention should be paid to the correction of the detected secondary metabolic disorders at the stage of preparing patients for further treatment. Since such a correction should be a separate stage in the patient's treatment.

Currently, the main methods to treat anemia in oncological diseases, in particular, caused by chemotherapy, is the transfusion of media containing erythrocytes and/or the administration of preparations of erythropoietin which stimulate erythropoiesis in combination (or without) with iron preparations for parenteral (intravenous) administration.

Considering all of the above and the quite obvious reasons, namely, the secondary metabolic disorders of serotonin, histamine, heparin which 
manifested by a significant increase in their plasma level of patients with AMN (AND?) in CRC, we suggested the need to use a medicinal product in a complex of therapeutic measures which can cause antihypoxic, membrane stabilizing and anti-edema action. Since we did not find such works in the scientific literature available to us, it was decided based on clarifying the state of serotonin, histamine, heparin metabolism in the blood plasma of patients with AND in CRC, to increase the treatment efficacy by improving the drug therapy regimen.

As we noted above, all patients with AND in CRC were divided into two subgroups depending on the inclusion of arginine glutamate, which causes both antihypoxic and membrane stabilizing action, in addition to the basic therapy. The following groups were formed: a group of patients who received the indicated drug (IIA, $(\mathrm{n}=180,98$ men and 82 women) and a group of patients who received the basic therapy only (IIB, $(n=212,108$ men and 104 women).

The safety study results of the arginine glutamate use in the treatment of patients with AND with CRC at the stage of preparation for further treatment are given in Table 2.

Table 2. The plasma level of FHN, FH, FS of patients with AND in $\mathrm{CRC}$ after treatment with arginine glutamate use (M $\pm \mathbf{m})$

\begin{tabular}{|c|c|c|c|}
\hline $\begin{array}{c}\text { Studied } \\
\text { parameter, unit } \\
\text { of measurement }\end{array}$ & $\begin{array}{c}\text { Patients } \\
\text { of IA group } \\
(\mathbf{n}=\mathbf{1 8 0})\end{array}$ & $\begin{array}{c}\text { Patients of } \\
\text { IB group } \\
(\mathbf{n = 2 1 2})\end{array}$ & $\begin{array}{c}\text { Significance } \\
\text { of differences } \\
\mathbf{( p )}\end{array}$ \\
\hline Level of FHN, $(\mu \mathrm{g} / \mathrm{g})$ & $23.54 \pm 0.51$ & $27.83 \pm 0.51$ & $\begin{array}{l}\mathrm{p}_{1}>0,1 \\
\mathrm{p}_{2}<0,001 \\
\mathrm{p}_{3}<0,05\end{array}$ \\
\hline Level of FH, (nmol/g) & $1.74 \pm 0.18$ & $2.84 \pm 0.38$ & $\begin{array}{l}\mathrm{p}_{1}>0,1 \\
\mathrm{p}_{2}<0,001 \\
\mathrm{p}_{3}<0,01\end{array}$ \\
\hline Level of FS, (nmol/g) & $1.21 \pm 0.10$ & $1.45 \pm 0.11$ & $\begin{array}{l}\mathrm{p}_{1}>0,1 \\
\mathrm{p}_{2}<0,001 \\
\mathrm{p}_{3}<0,05\end{array}$ \\
\hline Ratio FH:FS & $1.43 \pm 0.04$ & $1.96 \pm 0.05$ & $\begin{array}{l}\mathrm{p}_{1}>0,1 \\
\mathrm{p}_{2}<0,001 \\
\mathrm{p}_{3}<0,05\end{array}$ \\
\hline
\end{tabular}

Notes: $\mathrm{p}_{1}$ - the significance of differences between values depending on gender; $\mathrm{p}_{2}-$ the significance of differences between values in comparison with the control group; $\mathrm{p}_{3}-$ the significance of differences between values of patients in IIA and IIB groups 
As can be seen from Table 2, after the inclusion of arginine glutamate, which was administered at the beginning of treatment at a dose of $0,25 \mathrm{~g}$ orally three times a day after a meal for 14 days, in concomitant therapy of patients from IIA group, the plasma level of FHN, FH, FS significantly decreased $(\mathrm{p}<0,05)$ after 2 weeks and the FH:FS ratio in blood plasma normalized $(\mathrm{p}<0,05)$, which was indirect evidence of reduced severity of intoxication syndrome in patients of IIA group.

\section{Conclusions}

1. Anemia in neoplastic disease in CRC is accompanied by significant changes in the metabolism of biologically active substances - free fractions of heparin, histamine, serotonin, and the ratio of free histamine to serotonin.

2. The main methods of treating anemia in cancer are the administration of iron preparations parenterally (intravenously), erythropoietin preparations, transfusion of erythrocyte-containing media. The pathogenetically oriented method of treatment of patients with anemia in neoplasm disease in CRC has been improved and introduced into practice. It has a good perspective and consists of administration of a drug, which has an antioxidant, anti-edemic, and membrane-stabilizing action, in the addition to the basic therapy. The administration of arginine glutamate, which causes both antihypoxic and membrane-stabilizing action, in addition to the baseline therapy reliably contributes to the normalization of secondary metabolic disorders of histamine, serotonin and heparin metabolism in anemia in neoplastic disease in patients with CRC.

\section{Література}

1. Бережная Н. М., Чехун В. Ф. Иммунология злокачественного роста. Киев: Наукова думка, 2005. 792 с.

2. Бережная Н. М. Сімейства интерлейкинов: биология и онтогенез. Киев: Наукова думка, 2013. 576 с.

3. Видиборець С. В., Андріяка А. О. Фізіологічна роль гепсидину як центрального регулятора метаболізму заліза (огляд літератури).

\section{References}

1. Berezhnaya NM, Chekhun VF. Immunologiya zlokachestvennogo rosta [Immunology of tumor growth]. Kyiv: Naukova dumka, 2005. 792 p. [in Russian].

2. Berezhnaya NM. Semeystva interleykinov; biologiya i onkogenes [The families of interleukins: Biology and onkogenesis]. Kyiv: Naukova dumka, 2013. 576 p. [in Russian].

3. Vydyborets SV, Andriiaka AO. Fiziologichna rol gepsidinu jak zentralnogo regulyatora meabolizmu zaliza (oglyad literatury) [The 
Сімейна медицина. 2017; 1(69): 154-157.

4. American Cancer Society (2010) American Cancer Society: Cancer Facts and Figures 2010. Atlanta, GA:66-71.

5. World Cancer Research Fund International. Available at: http://www.wcrf.org

6. Greer J.P., Arber D.A., Glader B. (eds.) Wintrobe's clinical hematology. Philadelphia: Lippincott Williams \& Wilkins, 2014. 2278 p.

7. Федоренко 3. П., Колеснік О. О., Гулак І. О., Рижов А. Ю., Сумкіна О. В. Колоректальний рак в Україні: епідеміологічні та організаційні аспекти проблеми. Практична онкологія. 2019; 2: 9-16.

DOI: $10.22141 / 2663-3272.2 .2 .2019$. 176026

8. Лінчевський О. В., Ковальов О. О., Колеснік О. О., Безносенко А. П. Злоякісні новоутворення в Україні (аналітико-статистичний довідник) Практична онкологія. 2019; 2: 59-118. DOI: $10.22141 / 2663-3272.2 .2 .2019$. 176034

9. Луньова Г. Г. (ред.) Клінічна біохімія: керівництво. Київ: Атіка, 2013. 1156 c.

10. Бублій Ю. С. Гепарин: фізіологічна роль $\mathrm{i}$ клінічне значення порушень вмісту. Український жур- physiological role of hepcidin as a central regulator of iron metabolism (literature review). Simejna medyzyna. Family medicine. 2017; 1(69): 154-157. [in Ukrainian].

4. American Cancer Society (2010) American Cancer Society: Cancer Facts and Figures 2010. Atlanta, GA:66-71.

5. World Cancer Research Fund International. Available at: http://www.wcrf.org

6. Greer J.P., Arber D.A., Glader B. (eds.) Wintrobe's clinical hematology. Philadelphia: Lippincott Williams \& Wilkins, 2014. 2278 p.

7. Fedorenko ZP, Kolesnik OO, Gulak IO, Ryzhov AY, Sumkina OV. Kolorektalnyi rak v Ukraini: epidemiologichni ta organizatsijni aspekty problemy [Colorectal cancer in Ukraine: the epidemiological and organizational aspects of the problem]. Prakticna onkologia. Practical oncology. 2019; 2: 9-16.

DOI: 10.22141/2663-3272.2.2.2019. 176026. [in Ukrainian].

8. Linchevskii OV, Kovaliov OO, Kolesnyk OO, Beznosenko AP. Zlojakisni novoutvorennja $\mathrm{V}$ Ukraini (analityko-statystychnyi dovidnyk) [Malignant neoplasms in Ukraine (analytical and statistical reference book)]. Praktycna onkologia. Practical Oncology, 2019; 2: 59-118. DOI: $10.22141 / 2663-3272.2 .2$. 2019.176034 [in Ukrainian].

9. Luniova GG. (eds.) Klinichna biochimiia [Clinical Biochemistry]: Handbook. Kyiv: Atika, 2013. 1156 p. [in Ukrainian].

10. Bublij Yu. Heparyn: fiziologitchna rol' i klinitchne znatchennia porushen vmistu [Heparin: physiological 
нал гематології та трансфузіології. 2013; 6(17): 5-10.

11. Martin AM, Young RL, Leong L, Rogers GB, Spencer NJ, Jessup CF, Keating DJ. The diverse metabolic roles of peripheral serotonin. Endocrinology, 2017; 5: 1049-1063.

12. Mauler M, Bode C, Duerschmied D. Platelet serotonin modulates immune functions. Hamostaseologie, 2016; 1 : 11-16.

13. Halem E, El Banna N, Huang ME. Multifaceted roles of glutathione and glutathione-based systems in carcinogenesis and anticancer drug resistance. Antioxid Redox Signal. Nov. 2017; 20; 27(15): 1217-1234.

14. Corso CR, Asso A. Glutathione system in animal model of solid tumors: from regulation to therapeutic target. Crit. Rev. Oncol. Hematol. 2018; Aug. 128: 43-57.

15. Михайличенко Б. В., Видиборець С. В. Метод кількісного визначення гепарину в біосубстратах. Лабораторна діагностика. 2000; 4 : 53-56.

16. Михайличенко Б. В., Видиборець С. В. Метод одночасного флуориметричного визначення біогенних амінів в аналізованій пробі біосубстрату. Лабораторна діагностика. 1999; 2: 58-61. role and clinical meaning of the contens]. Ukrajinskij zhurnal gematologii i transfusiologii. 2013; 6(17): 5-10. [in Ukrainian].

11. Martin AM, Young RL, Leong L, Rogers GB, Spencer NJ, Jessup CF, Keating DJ. The diverse metabolic roles of peripheral serotonin. Endocrinology, 2017; 5: 1049-1063.

12. Mauler M, Bode C, Duerschmied D. Platelet serotonin modulates immune functions. Hamostaseologie, 2016; 1 : 11-16.

13. Halem E, El Banna N, Huang ME. Multifaceted roles of glutathione and glutathione-based systems in carcinogenesis and anticancer drug resistance. Antioxid Redox Signal. Nov. 2017; 20; 27(15): 1217-1234.

14. Corso CR, Asso A. Glutathione system in animal model of solid tumors: from regulation to therapeutic target. Crit. Rev. Oncol. Hematol. 2018; Aug. 128: 43-57.

15. Mykhailychenko B, Vydyborets S. Metod kil'kisnogo vyznatshennia geparynu v biosubstratah [Method of quantative determination of heparin in biological speciments]. Laboratorna diagnostika, 2000; 4: 53-56. [in Ukrainian].

16. Mikhailichenko BV, Vydyborets SV. Metod odnochasnogo fluorymetrychnogo vyznachennja biogennych aminiv $\mathrm{v}$ analizovanij probi biosubstratu [The metod of simultaneousfluorimetric assay of biogenic amines in biological speciments]. Laboratorna diagnostika, 1999; 2: 58-61. [in Ukrainian].

Надійшла: 16.08.2021

Контакти: aandriiaka0806@gmail.com 